\title{
The Importance of using Smart Boards in Teaching Small EFL Classes. A Case Study of College of Preparatory Year Programs (PYP), Majmmah University, KSA
}

\author{
Abdulghani Eissa Tour Mohammed \\ Assistant Professor of Applied Linguistics, College of Sciences and Arts \\ Araas, Qassim University, Kingdom of Saudi Arabia \\ Abdalgani71@yahoo.com \\ Eyhab Talal yaghi \\ $\mathrm{PhD}$ candidate at USM, Lecturer in English \\ College of Preparatory Year, Majmmah University \\ Kingdom of Saudi Arabia - P.O. Box 66 Almajmaa 11952 \\ etyaghi@gmail.com \\ Bilal Oqlah Bataineh \\ Instructor at College of Preparatory Year \\ Majmmah University, Kingdom of Saudi Arabia \\ bilal_bataineh@hotmail.com
}

\begin{abstract}
This paper focuses on the importance of using the smart board in small EFL classes. The researchers will go into the different ways to use it in lessons as well as answering the question how the smart board enhances EFL teachers to work effectively using Electronic learning tools. This paper will discuss the benefits of using the smart board in small EFL, in particular, it will study the case of Majmmah University, College of PYP. It will also discuss the benefits for teachers when using the smart board including, efficient lessons, engaging students, and the overall ease of use for the Smart board. A questionnaire was distributed among the EFL teachers during the academic year 2014-2015. The sample of the study consisted of (15) EFL teachers, randomly selected from the English Language teachers who are currently work at college of PYP. After collecting the data the researchers used the computer to conduct the necessary statistical processes, by the Statistical Package for the Social Sciences (SPSS). The researchers reached up to some findings, the most important of which are as follows:
\end{abstract}

1. Using smart boards in small classes improve EFL students' abilities to communicate.

2. It increases teacher-learner interaction

3. EFL teachers feel comfortable managing small classes.

Keywords: PYP, EFL, Small Classes, PTR, SB.






\section{INTRODUCTION}

During the academic year 2013 - 2014 the Preparatory Year Program (PYP), at Majmmah University has witnessed dramatically changes in terms of EFL teaching facilities as well as classroom size. As usual, decision makers at Majmmah University have invested more money to improve the process of learning and teaching EFL at college of PYP. For instance, classes of 20 students maximum which are internationally known as small classes became common in college of PYP. Smart boards and other teaching and learning facilities such as satellite TV, screens, speakers, laptops connected to the internet for all students and headphones also became part of each EFL class in PYP.

The impact of class size on students' performance is seen as a debatable issue, simply because it is difficult to separate between the class size and other uncontrollable variables such as teaching aids used. However, the literature review reveals that class size generally has a small and negative effect on students' retention, achievement, and engagement, development of communication skills, teaching evaluations, and teaching effectiveness. This paper attempts to investigate how small EFL classes at Majmmah University impacted the above mentioned variables. On the other hand, the study also endeavours to explore the impact of small class size in using smart boards effectively.

\subsection{Literature Review}

Based on aforementioned, the researchers thought to highlight the importance of smart boards in small EFL classes and their usage. Therefore, the they intend to explore the relationship between effective usage of smart boards in EFL classes and the class size. The literature review showed that many researchers have addressed the issue of class size and the importance of smart boards. This study attempts to brief the related literature on both class size domain as well as its impact on using smart boards. Class size debate will be discussed first, and then the study will shed light on the overall impact of small classes on using smart boards in EFL classes.

Class size is seen as a controversial issue, simply because investigating the impact of class size is difficult to be separated from other variables. However, the literature review reveals that class size generally has a small and negative effect on retention, achievement, engagement, development of communication skills, teaching evaluations, and teaching effectiveness.

Nonetheless, there is a big discrepancy among educators about the degree of the impact of class size on each of the above variables. Since students' involvement in the learning process is very important, the undertaken researches have shown that this involvement could be diminished in large classes.

\subsection{Students' Retention and Achievement}

Arias and Walker (2004), undertook a study. To control the lecture variable: two large classes (90 students), and two small classes (25 students) were submitted to the study. Based on the comparison of exam scores, they noticed that there is significantly a negative relationship between class size and students performance. In addition, students in small classes scored 3\% higher than their colleagues in large classes.

In 1997, taking into consideration the demographical variables, students of Binghamton University submitted to study which reveals that expanding class size affects negatively on student's achievement. The probability of students to receive (A) in class of 5 is $52 \%$. This was 2.4 times higher than students in class 290, where the probability of receiving (a) was $22 \%$. Also, student's achievement declined due to expanding class size. The study found that class size brought down the students achievement to lower rates. This implies that adding ten students to class of 10 has a negative effect more than adding ten students to class of 200. The study also investigates students return to university. It shows the probability of returning to university will be reduced if there is increasing in class size. Students with an average class size 20 have a probability of $97 \%$ to come back to university. In contrast, student's probability of returning back to university, with an average class size 240 , was only $80 \%$.

Kokkelenberg et.al (2008), in his study that lasted for four years, investigated 760000 observations of undergraduate in order to assess the impact of class size on student's grades. He found that the relationship between class size and students grades is significantly negative. For the sake of the study, researchers controlled a group of factors that includes peer effects, students ability, level of student, level of course, gender, minority status, and other relevant factors. The main result exposed in this study is that the effect of class size was more appeared as much as class getting larger. 
Robinson and Wittebols (1986) examined 100 relevant research studies using a related cluster analysis approach. They presumed that minimizing class size could be an advantage for lower students. They also added that to gain positive effect, teacher in small classes, should change their instructional techniques and procedures in the classroom.

Furthermore, Toth and Magnana (2002) studied the results of eight studies relevant to the impact of class size on students learning. Of the eight studies, three had mixed results; two scored greater learning in large classes, two found greater learning in small classes, and one study presented no effect of class size on learning.

Bedard and Khun (2008) inspected the effect of class size on student's evaluations. They used the data of all economics classes offered at the University of California, Santa Barbar from fall 1997 to spring 2004.The researchers found a noteworthy and large negative effect of class size on student's evaluations.

The results of research, at The University of Maryland, undertaken by Carbone and Greenberg (1998), revealed that just $25 \%$ of students agreed and $41 \%$ disagreed with the statement" the size of class does not affect my ability to learn". Moreover, students show that large classes are annoying and troublesome because of the absence of interaction with faculty, lack of lecture structure, and reduction in a number of tests in order to assess students understanding of materials.

Cooper and Robinson (2000) examined the teaching styles that his colleagues used in large classes. $80 \%$ of faculty $(\mathrm{n}=1800)$ have reported that lecture as their main pedagogical method in large classes. Recently, this percentage still unaltered. He pointed out that lecture method is the most appropriate method for large spaces, therefore, class size effects on students learning and plays a role in designs made for pedagogical choices that are taken in the classroom.

Joe Cusoe (2007) reviewed the literature on the class size and they concluded the following points: 1) large classes rise teachers' dependency on the lecture as instruction method, 2) large classes minimize students' participation in learning process, 3) teacher frequency and quality of interaction with and feedback to students will be diminished due to large classes, 4) reduction of students' attempts to think deeply inside classroom, 5) large class size restrict the instructors to broaden the course material and make it more deeply, 6) students' academic achievement and academic performance are declined in courses taught in large classes, 7) students report less satisfaction toward courses in large classes, 8) the students report lower overall ratings for course instruction delivered in large classes.

Fisher and Grant (1983), made an analysis for audio tapes of 155-class sessions in 40 undergraduates courses at different institutions. They noted that class size notably impacted the level of cognitive skills used by students in the classroom. In their way to examine students response to instructorposed questions, they found that small classes (15 or fewer students) average level of thinking was analysis, in medium-size classes (16-45) students discourse was referred to a lower level of thinking comprehension; while large classes (46 or more students), students discourse was featured as factual recall.

Kuh, et al. (1991), in a multi-campus observation based study, the researcher indicated that large classes are main obstacle prevent students' engaging in courses. In addition, students in large classes do not have the space to interact with the professor.

Mitchell and Beach have undertaken meta - analysis (1990). It shows that class size has an accumulative effect on students' learning. Also, meta-analysis exposes that class size decreases improvement of both students' and teachers' attitudes.

Wulff, Nyquist, and Abbot (1987), survive the perceptions of 800 college students enlisted and submitted in large- sized introductory courses at the University of Washington. Students raised different points:

1. It is easy to lose attention.

2. Being distracted because of classroom noise and students side talks.

3. There is no consideration of individuality in large classes, and consequences less motivated students. 


\subsection{Smart Boards}

Smart Board is an interactive electronic whiteboard. This board is connected to a computer and to a projector that displays the image of a computer screen. SMART board works through a piece of software that allows the users to use SMART Board for different purposes. According to (Shenton \& Pagett, 200); Smart board is first produced in 1991. It began to be used in education in late 1990s (Beeland, 2002).However, it has been given several names including Interactive White Board, Electronic White Board or Smart Board. It can be described, in technical terms, as "a touch-sensitive screen that works in conjunction with a computer and a projector" (SMART, 2006, p. 5).

The literature review shows that Smart board play a vital role in learning process, particular when it comes to learning foreign languages. The following are some advantages of using smart board:

\section{- Smart Boards' Contribution to Instructional Excellence}

SB technology plays an important role in making the whole-class teaching more effective, productive, and creative (Elaziz, 2008; Lan \& Hsiao, 2011. Moreover, SBs also enable the teachers to plan their lessons more effectively (Levy, 2002). Teachers can also conduct lessons in a more organized and planned way, as well as facilitating reflective practices using SBS (Schuck \& Kearney, 2007).

\section{- SBs' Contribution to Learning}

In terms of its direct contribution to instructional excellence, especially through multimedia capability and variety of sources, smart board supports students' learning indirectly (Beeland, 2002). Additionally, it supports learning by enhancing motivation, student engagement and active participation to lessons, hands-on applications, interaction, attention, and taking individual differences into consideration.

On the hand, studies have shown that smart boards enhance both EFL teachers and students to conduct different activities while teaching and learning English. Here are some of such activities:

\section{- Activities involving SMART Board in the Foreign Language Classes}

The impact of smart board on foreign language classes is seen from two different points of view: first, teachers' point of view, and that of the students' ones.

\section{- Activities which Support Teaching}

SMART Board supports the teaching process of foreign languages in three main ways: 1) it helps the presentation of new linguistic and cultural elements, 2) it supports interaction with the class and 3) it promotes the teacher's organizational skills.

\section{- Activities Supporting Interaction with Students}

Smart Board facilitates the role of teachers in creating strong rapport with students. It allows the teacher to navigate from the board, he/she does not have to go to his computer, turn his back to the class, and be more focused on the technology than on the learning process of the students. This point is very important when using SMART Board to teach and is crucial in foreign language classes. Every foreign language teacher knows how difficult it is to have a relaxed conversation with students in the target language. The projection makes it easier to start a conversation on a topic since it allows a group to watch a document at the same time and focus on the same point of the classroom. The merit of SMART Board is that it enhances conversation: when the teacher is navigating the document from the board, he faces and interacts with the class. It allows the instructor to focus on the students' language production and conversations, not on technical issues.

\section{- Activities Supporting Teacher Organization}

Regarding class room organization, smart board supports teachers to organize EFL classes effectively. For instance, keeping track of vocabulary introduced in class is a major organizational issue in foreign language teaching, especially in more advanced classes. The feature of SMART Board that allows the teacher to save the notes written on the board during the class supports this process tremendously. It helps teachers to remember those words and promotes their reinforcement: the teacher knows exactly the new elements he has introduced and is better able to work on reinforcing each of them. 
The Importance of Using Smart Boards in Teaching Small EFL Classes. A Case Study of College of Preparatory Year Programs (PYP), Majmmah University, KSA

- Activities supporting the Learning Process1)Activities Supporting Oral Skills

According to Pennigton $(1996,10)$ "computer can sometimes encourage a form of anti- social 'behavior that amounts to working in isolation from others". A common criticism of computer use, this is especially relevant in the context of foreign language classes because we are supposed to interact as much as possible in the target language.

\subsection{Activities Supporting the Cognitive Process}

Moreover, studies have also shown that Smart Board supports and enhances the learning process in many ways. One basic feature of SMART Board is the possibility of overwriting any projected document. This allows the students to know exactly what they need to focus on. It helps them to not get lost and to always know exactly what the teacher wants them to select from the document. If the teacher wants to emphasize any particular structure used on a web page, he can underline it with different colors. The various overwriting possibilities presented by SMART Board (colored underline, highlighting, circling) help the students to organize the new concepts. It is a valuable visual learning tool.

\subsection{Smart Board usage in EFL Classes}

Many instructors may not be mindful of the profits of utilizing a Smart Board as a part of the classroom instructing device. While the traditional whiteboard as of now has everybody's consideration, the electronic device is another innovation that is gradually picking up prominence because of its intelligent and interactive power.

The digital screen permits pictures from the machine to be shown on the board. It can likewise be changed on the screen itself, utilizing a pen or a highlighting device. Its touch screen peculiarity allows educators to run programs straightforwardly from the screen just by tapping the application with her/his finger and even makes scrolling simple.

Smart Boards are turning into a fundamental part of each classroom. A few explanations behind this:

- It can suit different learning styles. Learners can utilize the screen and learn by touching and writing at the board, and they can have a discussion and visual learners can watch teaching on the board.

- It is neater and does not have the cleanliness bother and is hence simpler to maintain.

- Most instructors are fully aware of the "why" yet discussions and concerns with the "how". To answer this question, here are a few tips on how you can utilize Smart Boards.

- Use it as an apparatus for note-taking. Learners can come and compose noteworthy notes on the board. Otherwise, you can choose a student to sort out notes on the machine while you talk, and other students can view and bring them down.

- Brainstorming in the classroom can be funny with a Smart Board. You can assemble content/ thoughts as well as pictures, outlines or features.

- Classrooms games can be played without any difficulty on the board. Boards games specifically can be played on the board itself.

- All types of media- features, photos, diagrams, maps, delineations, games, and so forth - can be utilized on the board, making it unimaginably changing in nature. This grows the scope of materials that you can use for showing or exhibiting new data.

The Smart Board is present and future's technology and is inevitable to change the look of classrooms until the end of time. Utilizing smart board as a part of your classroom can help you to be in touch with technology that could make the instruction process easier and maybe significantly more productive.

\section{MATERIAL AND MeThOdS}

The researchers have collected the required data for the current study through the use of a questionnaire addressed to EFL teachers. The aim of the questionnaire was to gather the necessary data as relates to the teachers' attitudes towards the importance of using smart boards in teaching 
Abdulghani Eissa Tour Mohammed et al.

small English classes in college of PYP. The study targeted EFL teachers in particular. A questionnaire of (20) items was distributed to a sample of (15) EFL teachers randomly selected.

In order to check the apparent validity of the study questionnaire and the validation of its statements according to the formulation and explanation, the researchers conducted a pilot test that. After collecting the data, the researchers conducted statistical calculation to analyse the data collected. The statistical calculation and the results analysed, confirmed the validity of the hypotheses. The following tables show the data analysis.

\subsection{Re liability Testing}

Table no. (1). Reliability Statistics for D1.

\begin{tabular}{|l|l|}
\hline Cronbach's Alpha & N of Items \\
\hline .799 & 10 \\
\hline
\end{tabular}

The above table shows that the first ten items of the questionnaire are valid according to the statistical calculation and the results analysed. As shown in figures according to Cronbach's Alpha the validity rate isabove seven which confirmed the validation of the questionnaire.

Table no. (2). Reliability Statistics for D2.

\begin{tabular}{|l|l|}
\hline Cronbach's Alpha & N of Items \\
\hline .835 & 10 \\
\hline
\end{tabular}

The above table shows that the second ten items of the questionnaire are valid according to the statistical calculation and the results analysed. As shown in figures according to Cronbach's Alpha the validity rate is above eight which confirmed the validation of the above questionnaire.

\section{Test 2: Measures of Dispersion \& Measures of Central Tendency}

Table no (3). Descriptive Statistics for D1.

\begin{tabular}{|l|l|l|l|l|}
\hline D1 & $\mathrm{N}$ & Mean & Std. Deviation & Variance \\
\hline Q1 & 20 & 1.20 & .616 & .379 \\
\hline Q2 & 20 & 1.20 & .616 & .379 \\
\hline Q3 & 20 & 1.65 & .933 & .871 \\
\hline Q4 & 20 & 1.10 & .447 & .200 \\
\hline Q5 & 20 & 1.20 & .616 & .379 \\
\hline Q6 & 20 & 1.10 & .447 & .200 \\
\hline Q7 & 20 & 1.05 & .224 & .050 \\
\hline Q8 & 20 & 1.25 & .639 & .408 \\
\hline Q9 & 20 & 1.30 & .733 & .537 \\
\hline Q10 & 20 & 1.20 & .616 & .379 \\
\hline D1 & 20 & 1.2250 & .28996 & .084 \\
\hline
\end{tabular}

The above table shows the descriptive statistics for the measures of dispersion of central tendency regarding items (1-10) of the questionnaire.

Table no (4). Descriptive Statistics

\begin{tabular}{|l|l|l|l|l|}
\hline D2 & $\mathrm{N}$ & Mean & Std. Deviation & Variance \\
\hline Q11 & 20 & 1.20 & .616 & .379 \\
\hline Q12 & 20 & 1.50 & .889 & .789 \\
\hline Q13 & 20 & 1.40 & .821 & .674 \\
\hline Q14 & 20 & 2.00 & .973 & .947 \\
\hline Q15 & 20 & 1.40 & .821 & .674 \\
\hline Q16 & 20 & 1.65 & .933 & .871 \\
\hline Q17 & 20 & 1.10 & .447 & .200 \\
\hline Q18 & 20 & 1.30 & .657 & .432 \\
\hline Q19 & 20 & 1.80 & .951 & .905 \\
\hline Q20 & 20 & 2.00 & 1.026 & 1.053 \\
\hline D2 & 20 & 1.4850 & .50915 & .259 \\
\hline
\end{tabular}

The above table shows the descriptive statistics for the measures of dispersion of central tendency regarding items (11-20) of the questionnaire. 
The Importance of Using Smart Boards in Teaching Small EFL Classes. A Case Study of College of Preparatory Year Programs (PYP), Majmmah University, KSA

Table no (4). Test 3: Frequencies

\begin{tabular}{|c|c|c|c|c|c|c|}
\hline \multirow[t]{2}{*}{ Variable } & \multicolumn{3}{|c|}{ Frequencies } & \multicolumn{3}{|c|}{ Frequencies (\%) } \\
\hline & 1 & 2 & 3 & $\mathbf{1}$ & 2 & 3 \\
\hline Q1 & 18 & 0 & 2 & $90 \%$ & $0 \%$ & $10 \%$ \\
\hline Q2 & 18 & 0 & 2 & $90 \%$ & $0 \%$ & $10 \%$ \\
\hline$\overline{\mathbf{Q 3}}$ & 13 & 1 & 6 & $65 \%$ & $5 \%$ & $30 \%$ \\
\hline Q4 & 19 & 0 & 1 & $95 \%$ & $0 \%$ & $5 \%$ \\
\hline Q5 & 18 & 0 & 2 & $90 \%$ & $0 \%$ & $10 \%$ \\
\hline Q6 & 19 & 0 & 1 & $95 \%$ & $0 \%$ & $5 \%$ \\
\hline Q7 & 19 & 1 & 0 & $95 \%$ & $5 \%$ & $0 \%$ \\
\hline Q8 & 17 & 1 & 2 & $85 \%$ & $5 \%$ & $10 \%$ \\
\hline Q9 & 17 & 0 & 3 & $85 \%$ & $0 \%$ & $15 \%$ \\
\hline Q10 & 18 & 0 & 2 & $90 \%$ & $0 \%$ & $10 \%$ \\
\hline D1 & 18 & 2 & 0 & $90 \%$ & $10 \%$ & $0 \%$ \\
\hline \multirow[t]{2}{*}{ Variable } & \multicolumn{3}{|c|}{ Frequencies } & \multicolumn{3}{|c|}{ Frequencies (\%) } \\
\hline & 1 & 2 & 3 & 1 & 2 & 3 \\
\hline Q11 & 18 & 0 & 2 & $90 \%$ & $0 \%$ & $10 \%$ \\
\hline Q12 & 15 & 0 & 5 & $75 \%$ & $0 \%$ & $25 \%$ \\
\hline Q13 & 16 & 0 & 4 & $80 \%$ & $0 \%$ & $20 \%$ \\
\hline Q14 & 9 & 2 & 9 & $45 \%$ & $10 \%$ & $45 \%$ \\
\hline Q15 & 16 & 0 & 4 & $80 \%$ & $0 \%$ & $20 \%$ \\
\hline Q16 & 13 & 1 & 6 & $65 \%$ & $5 \%$ & $30 \%$ \\
\hline Q17 & 19 & 0 & 1 & $95 \%$ & $0 \%$ & $5 \%$ \\
\hline Q18 & 16 & 2 & 2 & $80 \%$ & $10 \%$ & $10 \%$ \\
\hline Q19 & 11 & 2 & 3 & $55 \%$ & $10 \%$ & $15 \%$ \\
\hline Q20 & 10 & 0 & 10 & $50 \%$ & $0 \%$ & $50 \%$ \\
\hline D2 & 12 & 7 & 1 & $60 \%$ & $35 \%$ & $5 \%$ \\
\hline
\end{tabular}

The above table shows the test frequencies for the whole 20 items of the questionnaire.

\section{(A) Questionnaire Items (part one)}

\begin{tabular}{|l|}
\hline The impact of small classes in teaching EFL. \\
\hline 1- Small class improves students' language skills. \\
\hline 2- Students learn to work together. \\
\hline 3-students learn how to correct themselves. \\
\hline 4- Students improve their learning skills. \\
\hline 5- Students enjoy their subjects in small EFL classes. \\
\hline 6- It increases teacher-student interaction. \\
\hline 7- A teachers can easily remember a student outside the classroom. \\
\hline 8- There is a lot of fun in small EFL classes. \\
\hline 9- In small EFL classes, students can exchange ideas and build relations with their peers. \\
\hline 10- - In small EFL classes, the atmosphere is quite. \\
\hline
\end{tabular}

Table no (5). Frequencies for D1.

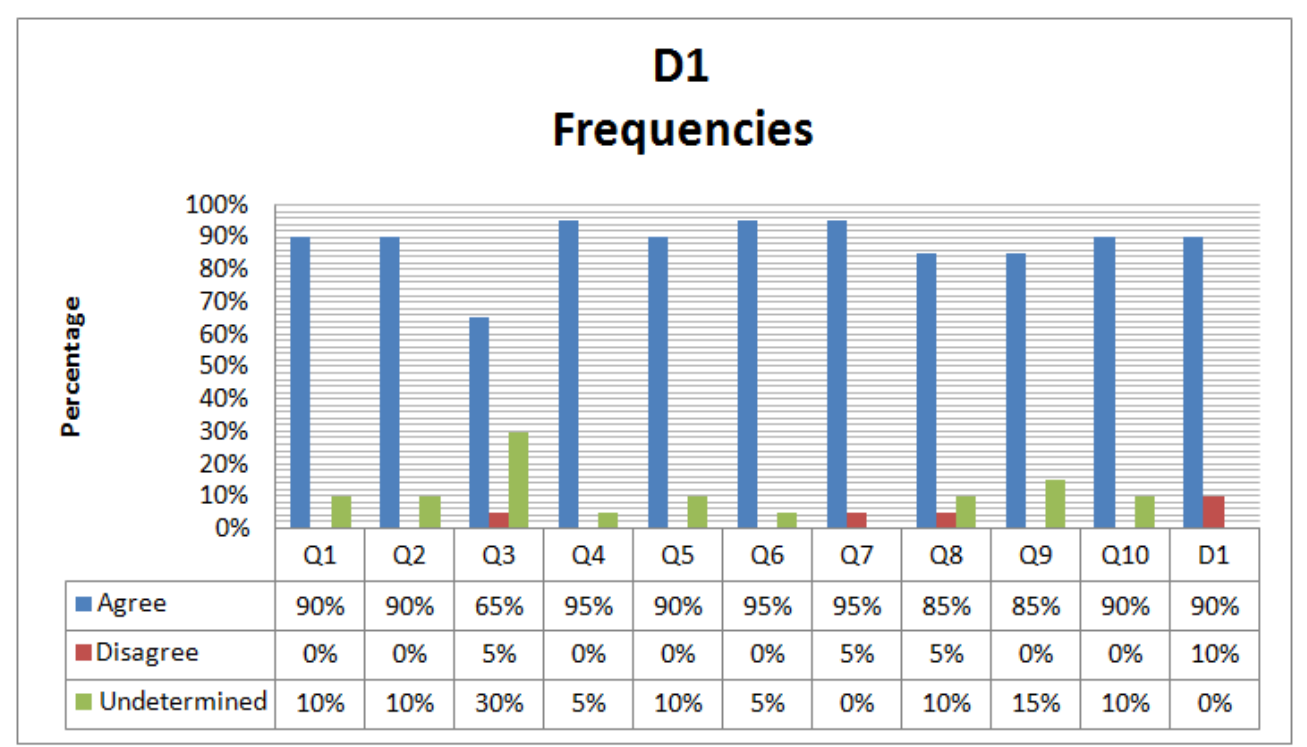


The above table illustrates that small classes have great influence in improving EFL teachers' performance. For instance, items $(4,6,7)$ received the highest percentage of agreement by the respondents as shown in the table. It is agreed that small classes improve students' learning skills. It also increases student- teacher interaction as well as creating a strong rapport between them. Additionally, the table shows that the respondent also strongly agreed with the following items $(1,2,5,8,9,10)$, approximately $80 \%$ and above confirmed their impact on small classes. The only exception shown in the above table is that $30 \%$ undermined to what extent students can learn how to correct themselves in small classes, this view point is illustrated by question3.

Although class size is considered a debatable issue by many applied linguists, but the good news shown by the above table is that small EFL class has a significant impact on overall teaching performance. For example, teaching English in small classes makes it possible for both EFL teachers and students to have strong rapport inside and outside the classroom.

The above table proves that small class enhances EFL teachers to communicate with students effectively; they also interact easily with them as individuals since everyone has a chance to ask and participate in answering questions. Moreover, some students may have fun working in small groups, implementing cooperative learning via which they can exchange ideas as well as learning from each other. The only exception shown in the above table is that $30 \%$ of the respondents have undermined to what extent students can learn how to correct themselves in small classes.

\section{(B) Questionnaire Items (part two)}

\begin{tabular}{|l|}
\hline The importance of Smart Boards in Enhancing the Abilities of EFL teachers \\
\hline I1- I feel comfortable using smart boards in an small EFL classroom. \\
\hline 12- It increases students' concentration in small EFL classes. \\
\hline 13- It facilitates interaction between the students and the teacher. \\
\hline 14-It improves ability of self-concept. \\
\hline 15-It increases the ability of understanding lectures. \\
\hline 16- It facilitates the process of problem solving. \\
\hline 17-It increases the ability of using technologies in small classes. \\
\hline 18-It encourages teachers to focus on extra classroom activities in small classes. \\
\hline 19-It turns the classes into learner - centred. \\
\hline 20- It develops the level of invention and brain storming. \\
\hline
\end{tabular}

Table no (6). Frequencies for D2.

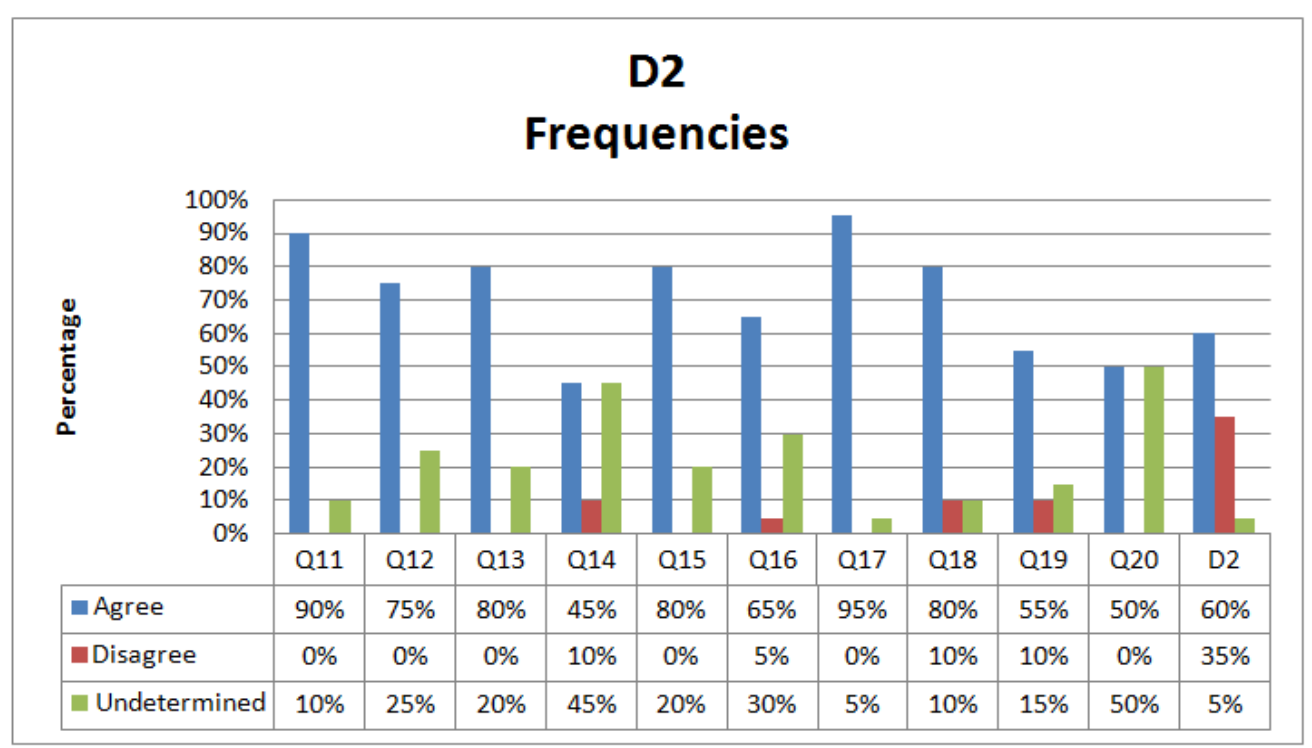

As shown in the above table smart boards can positively impact both EFL teachers' and students' performance, items $(11,17$, and 18) are clear evidences because of the high percentages they received. In figures the table illustrates that teachers feel comfortable using smart boards as an electronic tool in EFL classes. Implementing electronic teaching tools have become common in today's EFL classes all over the world. The table also shows that using smart boards provide teachers with extra to find more extra classroom activities resources; this situation may increase students' motivation in doing their home works. On the other hand, respondents are not sure about the impact of smart boards in EFL 
The Importance of Using Smart Boards in Teaching Small EFL Classes. A Case Study of College of Preparatory Year Programs (PYP), Majmmah University, KSA

classes when it comes to improving self-concept, problems solving, turning the class into learnercentred and developing brainstorming. To sum up, we can say that smart boards have a positive influence in teaching EFL as well as improving teachers' performance. However, the study shows that teachers can easily use smart boards in small classes. As confirmed by item (1), teachers feel comfortable in small classes because they face few students in a well-equipped class where electronic teaching aids are common. This situation may create an atmosphere of an individual interaction between the teachers and students; it may bring more fun which will definitely increase students' motivation towards language learning.

\section{SUMMARY AND FINDINGS}

This paper has investigated the attitudes of EFL teachers towards using smart boards in EFL small classes. problems arising from teaching English in Large Classes. It has focused on the EFL teachers who worked in College of PYP, Majmmah University during the academic year 2014-2015. For the statistical calculations of the study tools a questionnaire was distributed to the study sample (15 EFL teachers). The above figures and tables have clearly shown all the computational analysis that resulted into the following:

First, the study showed that small class enhances EFL teachers to communicate with students effectively; they also interact easily with them as individuals since everyone has a chance to ask and participate in answering questions. Moreover, some students have fun working in small groups, implementing cooperative learning via which they can exchange ideas as well as learning from each other.

On the other hand, the study showed that smart boards have a positive influence in teaching EFL as well as improving teachers' performance. Additionally, the study shows that teachers can easily use smart boards in small classes. As confirmed by item (1), teachers feel comfortable in small classes because they face few students in a well-equipped class where electronic teaching aids are common.

\section{REFERENCES}

Kokkelenberg, Dillon, and Christy. The Effects of Class Size on Student Grades at a Public University. 2008.

Binghamton University OIR. The Effects of Class Size on Student Performance and Retention at Binghamton University. 1997.

Hancock. Effects of Class Size on College Student Achievement. College Student Journal. 1996.

Arias and Walker. "Additional Evidence on the Relationship between Class Size and Student Performance." Research in Economic Education. 2004.

Baker, J. (2007). Smart board in the music classroom. Music Eduactors Journal, 93(5), 18-22. Retrieved November 28, 2011, from http://web.ebscohost.com

Burchill, P. (n.d.). Teaching English language learners more effectively. SMART education solutions. Retrieved November 27, 2011, from smarttech.com

Preston, C., \& Mowbray, L. (2008). Use of "SMART" boards for teaching, learning and assessment in kindergarten science. Teaching Science, 54(2), 50-57. Retrieved November 27, 2011, from http://web.ebscohost.com

Starkman, N. (2006). The wonders of interactive whiteboards. T.H.E. Journal, 33(10), 35-39. Retrieved November 28, 2011, from http://web.ebscohost.com

Sutman, F., \& Xin, J. (2011). Using the smart board in teaching social stories to students with autism. Teaching exceptional children, 43(4), 18-24. Retrieved November 27, 2011, from http://web.ebscohost.com 